\title{
Sustainable Development Goals: Their Impacts on Forests and People
}

Edited by

PIA KATILA

Natural Resources Institute Finland

CAROL J. PIERCE COLFER

Center for International Forestry Research and Cornell University

WIL DE JONG

Kyoto University

GLENN GALLOWAY

University of Florida

PABLO PACHECO

World Wildlife Fund and Center for International Forestry Research

GEORG WINKEL

European Forest Institute 


\section{Chapter 3 SDG 3: Good Health and Well-Being - Framing Targets to Maximise Co-Benefits for Forests and People}

Rosemary A. McFarlane*, John Barry, Guéladio Cissé, Maya Gislason, Marta Gruca, Kerryn Higgs, Pierre Horwitz, Giang Huu Nguyen, Jane O'Sullivan, Subhashis Sahu and Colin D. Butler

\section{Key Points}

- The achievement of SDG 3 depends on many other SDGs; some SDGs are logically inconsistent, especially in the attempt to increase conventionally defined GDP while preserving natural capital.

- Any short-term gains for human health from further forest conversion (e.g. food production) creates short- and long-term, direct and indirect health risks for humans, as well as for other biota.

- Failure to ensure universal access to sexual and reproductive healthcare services (including family planning) will increase pressure on forests at local, regional and global scales.

- The burning and clearing of forests cause significant harm to health via impaired quality of water, soil and air; increased exposure to infectious diseases and impacts climate regulation.

- Many infectious diseases are associated with forest disturbances and intrusions; some important infectious diseases have emerged from forests (notably HIV/AIDS).

- Greater exposure to green space, including forests, provides mental and physical health benefits for the growing global urban population.

\subsection{Introduction}

The third SDG is very ambitious. It includes the words 'health' and 'wellbeing', which both have lofty, multiple and contested meanings and aspirations. Echoing the almost-forgotten World Health Organization (WHO) slogan proclaimed at the Alma Ata conference in 1978 of 'health for all by the year 2000', SDG 3 proclaims the aspiration 'well-being for all' by 2030. However, this is a pledge for the world to promote this aspiration rather than

* Lead author. 
achieve it - a task probably considered unwisely ambitious, even by the SDG framers.

In 1948, the newly formed WHO defined human health as 'a state of complete physical, mental and social well-being and not merely the absence of disease or infirmity' (WHO 2019b). Then revolutionary, this definition challenged the disease-focused medical model of health that was (and is still) the common perception of not only lay people, but also many health workers. It challenged convention by recognising the importance of the social and mental dimensions of health.

In recent decades, the WHO definition has been increasingly criticised, mainly for its use of the word 'complete'. Today, in a world with so many people with chronic illnesses and disabilities, complete health is unattainable for hundreds of millions, perhaps billions. Indeed, some argue that the pursuit of complete health is counterproductive because it promotes the remedicalisation of the concept of health, allowing profit-seeking corporations such as pharmaceutical companies, the medical screening industry and often health workers themselves to seek opportunity and personal gain through new drugs, blurring the distinction between normal variation (including ageing) and pathology (Huber et al. 2011).

Unlike in 1948, many people today live reasonably fulfilling lives in their older years, while in the mid-twentieth century infectious diseases crippled and shortened the lives of many and were seen as the major global health problem. For young people with conditions such as undernutrition, hookworm or malaria, the potential of cure and a period of 'complete' health (lasting at least some decades following treatment) seemed a realistic aspiration for health workers in a milieu encouraged by the WHO in 1948. Today, suggesting that most 70-year-olds with diabetes or arthritis can become completely healthy is unrealistic. Nevertheless, 'rectangularising the curve' - maintaining good, though rarely (if ever) complete, health well into old age - remains an important goal. The pathways to this goal of excellent, albeit imperfect, lifelong health are increasingly understood in theory but remain out of reach for billions, as so many of the determinants of health remain fragile, damaged, endangered, unattainable and structural. Few are within the ability of individuals or communities to change.

A lesser known criticism of the WHO health definition is its lack of environmental or ecological dimension, including its relationship with forests. In 1990, the pioneer of primary health care, Maurice King, suggested that the WHO insert 'sustainable' as the second word in its health definition (King 1990). Like all other suggested amendments, this has been resisted so far. However, there is increasing understanding, including within the WHO, that there are crucial environmental underpinnings of health and that many of 
these determinants lie far beyond the expertise of clinicians - that is, of doctors and other health workers who encounter and treat the sick.

The Declaration of the Alma Ata conference identifies two of eight essential components of primary health care as environmental: (1) adequate nutrition, and (2) safe water and basic sanitation. The 1986 Ottawa Charter, a landmark in health promotion, pays even more attention to environmental issues. It declares that the fundamental conditions and resources for health are 'peace, shelter, education, food, income, a stable ecosystem, sustainable resources, social justice and equity' (WHO 1986). These (and others) have become known as the social (and environmental) determinants of health and are considered to determine the inequity of health outcomes among populations. Many of these conditions and resources are related to other SDGs, illustrating a difficulty not only for this chapter but also for the others. Virtually all 17 SDGs are related to health and well-being in some way, as well as to each other. One risk of the SDG approach is inadvertently reinforcing barriers among disciplines and lobby groups. On the other hand, progress with many SDGs is likely to have synergistic benefits: the WHO describes the SDGs as a blueprint for systematically addressing the social determinants of health (Government of South Australia and WHO 2017).

Although this chapter focuses on forests, health and well-being through the lens of specific SDG 3 targets (for the complete list, see Table 3.1), we stress that the public goods (the 'ends') of health and well-being have many non-environmental determinants, including caste, class, corporate, cultural, economic, educational, epigenetic, ethnic, gender, genetic, nutritional, political, social and spiritual aspects. These are listed alphabetically to stress that they are all important; prioritising any one is subjective. We acknowledge that some analysts will argue that some categories (e.g. social) may embrace subsets (e.g. political). No framework of analysis will satisfy everyone. An analogy from biology is of survival. Humans need air, water and food, but death from suffocation is fastest: this does not mean air is more important than food, considered over a longer period. While humans may survive with only air, water and food - perhaps in a windowless cell they will certainly not thrive with those inputs alone. Other aspects, such as social connections, are also vital to foster even an imperfect state of physical, mental and social well-being. Some of these relate to forests and their services.

Well-being is also a contested, context-dependent term. The WHO defines it as part of health, whereas the Millennium Ecosystem Assessment conceptual framework considers health as one of five components of wellbeing, along with material sufficiency, security, good human relations, and freedom and choice (Butler et al. 2003). 
This chapter discusses the impacts of achieving SDG 3 targets on forests, forest people and humans more broadly, including background on important connections between some specific SDG 3 targets and forests and their services. We argue that failure to make significant progress with Target 3.7, concerning sexual and reproductive healthcare services, will have significant adverse effects not only on forests, but on all other SDGs.

In Table 3.1 we highlight in bold those SDG 3 targets with forest connections discussed in detail in this chapter. The others are still relevant to forestdependent populations and are referred to within the sections.

Table 3.1 SDG 3 targets, highlighting those particularly pertinent to forests and forest populations (targets in bold have forest connections discussed in detail in chapter)

\begin{tabular}{|l|l|}
\hline Target & \multicolumn{1}{|c|}{ Description } \\
\hline 3.1 & $\begin{array}{l}\text { By 2030, reduce the global maternal mortality ratio to less than } 70 \\
\text { per 100 000 live births }\end{array}$ \\
\hline 3.2 & $\begin{array}{l}\text { By 2030, end preventable deaths of newborn and children under 5 } \\
\text { years of age, with all countries aiming to reduce neonatal mortality } \\
\text { to at least as low as } 12 \text { per } 1000 \text { live births and under-5 mortality to } \\
\text { at least as low as } 25 \text { per } 1000 \text { live births }\end{array}$ \\
\hline 3.3 & $\begin{array}{l}\text { By 2030, end the epidemics of AIDS, tuberculosis, malaria and } \\
\text { neglected tropical diseases and combat hepatitis, water-borne } \\
\text { diseases and other communicable diseases }\end{array}$ \\
\hline 3.4 & $\begin{array}{l}\text { By 2030, reduce by one-third premature mortality from non- } \\
\text { communicable diseases through prevention and treatment and } \\
\text { promote mental health and well-being }\end{array}$ \\
\hline 3.5 & $\begin{array}{l}\text { Strengthen the prevention and treatment of substance abuse, } \\
\text { including narcotic drug abuse and harmful use of alcohol }\end{array}$ \\
\hline 3.6 & $\begin{array}{l}\text { By 2020, halve the number of global deaths and injuries from road } \\
\text { traffic accidents }\end{array}$ \\
\hline 3.7 & $\begin{array}{l}\text { By 2030, ensure universal access to sexual and reproductive } \\
\text { health-care services, including for family planning, information } \\
\text { and education, and the integration of reproductive health into } \\
\text { national strategies and programmes }\end{array}$ \\
\hline 3.8 & $\begin{array}{l}\text { Achieve universal health coverage, including financial risk } \\
\text { protection, access to quality essential healthcare services } \\
\text { and access to safe, effective, quality and affordable essential } \\
\text { medicines and vaccines for all }\end{array}$ \\
\hline
\end{tabular}




\begin{tabular}{|l|l|}
\hline Table 3.1 (cont.) \\
\hline Target & $\begin{array}{l}\text { By 2030, substantially reduce the number of deaths and illnesses } \\
\text { from hazardous chemicals and air, water and soil pollution and } \\
\text { contamination }\end{array}$ \\
\hline 3.A & $\begin{array}{l}\text { Strengthen the implementation of the WHO Framework Convention } \\
\text { on Tobacco Control in all countries, as appropriate }\end{array}$ \\
\hline 3.B & $\begin{array}{l}\text { Support the research and development of vaccines and medicines for } \\
\text { the communicable and non-communicable diseases that primarily } \\
\text { affect developing countries, provide access to affordable essential } \\
\text { medicines and vaccines, in accordance with the Doha Declaration on } \\
\text { the TRIPS Agreement and Public Health }\end{array}$ \\
\hline 3.C & $\begin{array}{l}\text { Substantially increase health financing and the recruitment, } \\
\text { development, training and retention of the health workforce in } \\
\text { developing countries, especially in least developed countries and } \\
\text { small island developing States }\end{array}$ \\
\hline Source: https://sustainabledevelopment.un.org/sdg3 \\
\hline 3.D & $\begin{array}{l}\text { Strengthen the capacity of all countries, developing countries, for } \\
\text { early warning, risk reduction and management of national and } \\
\text { global health risks }\end{array}$ \\
\hline
\end{tabular}

\subsubsection{Health and Forests}

We conceptualise the links between forests and population health at three scales (Figure 3.1) (World Bank 2008). We also stress that the relationship is bidirectional: forest effects on health are not all positive, and people's improved well-being can have good and bad impacts on forests.

However, forests do have important benefits for health for all people. Most proximally, about 350 million people live very close to or within dense forests and are substantially dependent on them. Of these, about 60 million (mostly Indigenous) are wholly dependent on forest ecosystem services for food, water, fuel, medicine, culture and livelihood. At a second scale is a larger population, though of uncertain size, that lives away from the forest, may never even visit one and yet depends on and, in some cases, consciously consumes services such as drinking water, firewood or bushmeat. Across these two scales are at least 13.5 million people employed formally in forestry (Garland 2018).

Most of the global population is at the third scale; many are exposed on a frequent basis to the urban forest and may visit other forests on holiday. Most 


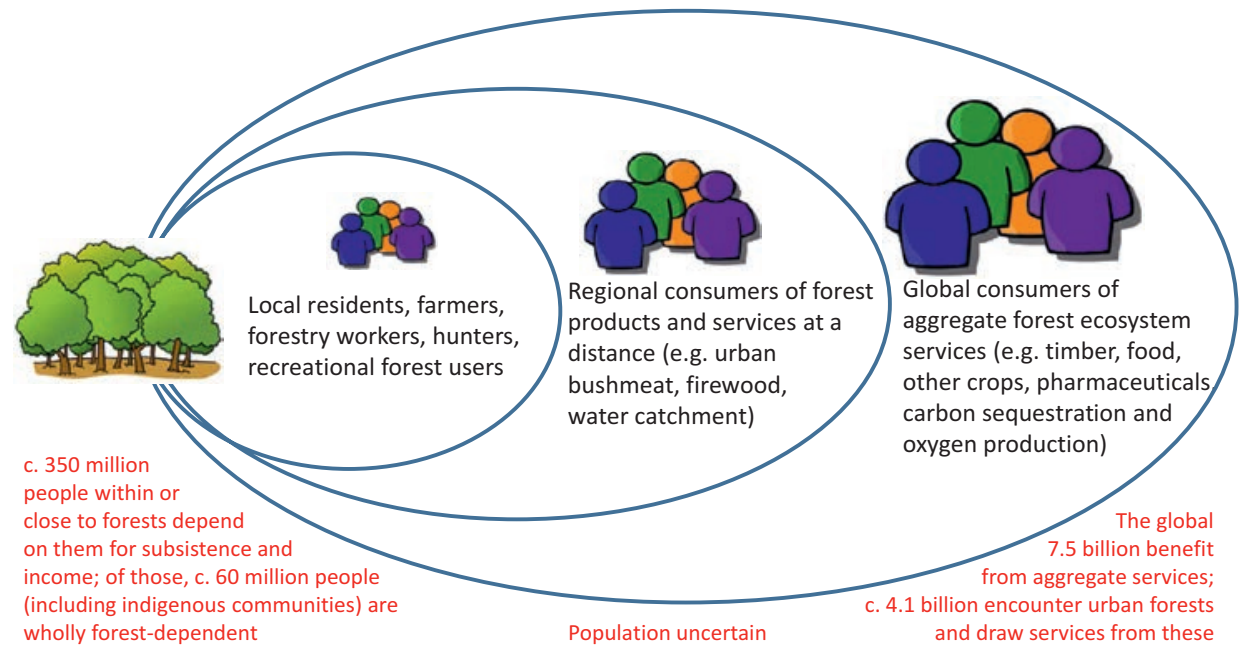

Figure 3.1 Multi-scale impacts of forests on the health and well-being of populations.

consume, often indirectly, forest products such as timber, food and pharmaceutical discoveries from around the world. This entire population benefits, whether they know it or not, from other services, especially the carbon-regulating and oxygen-providing functions of forests. A small but significant fraction of people in the second and third category consciously seek contact with forests (near and far), as well as with other aspects of nature. There is increasing appreciation that this group may experience direct health benefits.

\subsection{Sustainability, Limits, Population and the 'Free Market'}

The ecological impacts of achieving SDG 3 (and its specific targets), as with the other human-focused SDGs, need to be framed within the debates about ecological sustainability, population and market processes. These factors affect the pursuit of health and well-being for all and the fate of the world's forests. Importantly, decades of often-fluctuating concern about the impact of humans on natural resources have included warnings that exceeding the limits of natural resources is both possible and catastrophic for human well-being. As early as the 1970s, The Limits to Growth (Meadows et al. 1972) identified major aspects of future crisis brought on by accelerating industrialisation and population growth, leading to depletion of non-renewable resources and many forms of environmental decline. More recently, the planetary boundaries framework aims to establish the limits beyond which human activities fatally undermine the ecological integrity on which human life ultimately depends (Steffen et al. 2015). Forests are at the heart of three 
dangerous ecological trends. Biodiversity loss and biogeochemical disruption have already breached limits, while land-system change and climate disruption are approaching the danger zone.

The exploitation of natural resources is driven by economic (and population) growth and this highlights a fundamental concern: currently, achieving SDG 3 and most other human-centric SDGs requires ongoing economic growth. Healthcare and the well-being of the growing global (and local) populations of consumers is costly, and this has impacts on the environment and sometimes directly on forests. Forest transformation can provide local employment, generating cash and opportunities for financially poor and often vulnerable populations. It can also greatly increase food production. These opportunities can then be used to engage more broadly with the wider economy and to facilitate better education and healthcare. Earth system and population health concerns become lost in such discussions. Furthermore, existing market forces do little to protect nature or promote the broader social determinants of health.

Solutions to these problems require transformative thinking and alternative economic models. Impressive improvements in nutrition and health

in the early twenty-first century have been achieved in Ghana, Vietnam and Brazil, where government programmes provided benefits such as cash for mothers, support for smallholders and land grants (Lappé et al. 2013). Such programmes, which may ease the pressure on forests, are in opposition to current (neoliberal) economic principles. Alternative economic models that decouple economic growth from environmental degradation (Target 8.4) are required to safeguard health. This chapter discusses some integrated approaches to poverty, population, health and environmental management that seek optimal outcomes for both forests and people (see Box 3.2).

\subsection{Forests, People and SDG 3 Targets}

\subsubsection{Ending Epidemics and Controlling Communicable Diseases}

Target 3.3 specifically calls for ending epidemics of HIV/AIDS, malaria and tuberculosis (three major 'communicable' or 'infectious' diseases that are the focus of sustained global control efforts) and of a collection of diseases grouped because of neglect. A high population burden of communicable diseases is generally linked to poverty and underdevelopment. Poverty is deepened by ill health, the costs of seeking treatment and lost livelihood. The control of communicable diseases has increased globally with good health literacy (particularly regarding sanitation, food safety and minimising interpersonal, vector and zoonotic transmission of infections), vaccination 
programmes, surveillance and response. In poor countries and regions, the capacity and effectiveness of health systems to provide these services (Target 3.8) is often limited - particularly for remote communities, including those in forested regions.

Many important communicable diseases have little or no association with forest ecology (such as influenza, tuberculosis, viral hepatitis and sexually transmitted infections other than HIV), although they may affect forest-associated populations. However, seeking to fulfil Target 3.3 has implications for forest management with regards to malaria and some other forest-origin or associated diseases.

Malaria affects 219 million people, with almost half a million deaths (in 2017), 90 per cent in sub-Saharan Africa (WHO 2018a). The global campaign focuses on eradicating the malarial parasite with the use of insecticide-impregnated bed nets, domestic spraying, diagnosis and treatment (Bauhoff and Busch 2018). However, the density and activity of vector mosquito populations can be affected by deforestation, particularly in Asia and Latin America. Rutted ground and roads resulting from forest clearance, forest edges and cleared patches provide free-standing water, optimum temperature and protection from desiccation for mosquito development often transiently - and may favour vectors over non-vectors (Guerra et al. 2006). This knowledge can be used locally to reduce malaria through forest management, but is more commonly used to identify risk. Forest workers may be susceptible to local infection or exposed to new species of malaria as they penetrate new forests, as demonstrated in the emergence of monkey malaria (Plasmodium knowlsei) as a new human disease (Barber et al. 2017). Infected forest workers may also introduce malarial parasites to disease-free forests. In frontier settlements, children (highly susceptible), if not adults, will perpetuate and amplify malarial infection. Disease fronts can establish: 99 per cent of Brazil's malaria now occurs in the Amazon basin (Chaves et al. 2018).

The so-called Neglected Tropical Diseases with either significant prevalence in forest-based populations or with a link to forest transformation, positive or negative, are listed in Table 3.2. Many of these conditions afflict Indigenous and other forest-dwelling populations and are strongly associated with poverty, low health literacy and poor or underfunded health services (Target 3.8). Relatively simple medication, if available and affordable, can have a dramatic effect on many of these diseases. Forest management may also play a part in the prevention of some of these disease conditions.

HIV/AIDS is among a new group of infectious diseases, recognised since the 1970s, that have wildlife and environmental origins. For HIV/AIDS, its forest association is historic (Sharp and Hahn 2011). It is now a human-specific 
Table 3.2 Neglected tropical diseases and forests

\begin{tabular}{|c|c|c|c|c|c|c|}
\hline \multirow{2}{*}{$\begin{array}{l}\text { Neglected } \\
\text { tropical disease }\end{array}$} & \multicolumn{4}{|c|}{ Deforestation effect } & & \multirow[t]{2}{*}{ Comment } \\
\hline & Direct & In direct & Worsened & Improved & Mixed & \\
\hline $\begin{array}{l}\text { Schisto- } \\
\text { somiasis }\end{array}$ & & Y & Y & & & $\begin{array}{l}\text { Results from post-forest land-use change, particularly } \\
\text { involving water/irrigation; affects many tropical } \\
\text { regions, but not South Asia }\end{array}$ \\
\hline $\begin{array}{l}\text { Soil } \\
\text { transmitted } \\
\text { helminths }\end{array}$ & Y & $\mathrm{P}$ & Y & & & $\begin{array}{l}\text { Forest-to-crops conversion can change soil biodiversity; } \\
\text { decreased soil-pathogen competition promotes } \\
\text { threadworm/hookworm, especially with increased soil } \\
\text { moisture following flooding; increased site-contamination } \\
\text { for resettled (previously mobile) forest groups associated } \\
\text { with poor sanitation, bare feet, open defecation }\end{array}$ \\
\hline Buruli ulcer & & Y & Y & & & $\begin{array}{l}\text { Geographically associated with upper catchment areas; } \\
\text { also wetlands recently converted to farming }\end{array}$ \\
\hline $\begin{array}{l}\text { Chagas } \\
\text { disease }\end{array}$ & $\mathrm{Y}$ & & Y & & Y & $\begin{array}{l}\text { Associated with forest workers/poor housing; } \\
\text { deforestation favours synanthropic triatominae (e.g. } \\
T \text { cruzi) and wild mammal hosts, amplified in palm oil } \\
\text { plantations }\end{array}$ \\
\hline $\begin{array}{l}\text { Leishmaniasis } \\
\text { (Kala Azar) }\end{array}$ & $\mathrm{Y}$ & & $\mathrm{Y}$ & & $\mathrm{Y}$ & $\begin{array}{l}\text { Associated in Latin America with forest clearing/ } \\
\text { residential expansion and synanthropic vector/host } \\
\text { combinations; some vector sand fly and host wildlife } \\
\text { species persist in modified/plantation forest; associated } \\
\text { in Sudan with forest/peri-forest exposure }\end{array}$ \\
\hline
\end{tabular}




\begin{tabular}{|c|c|c|c|c|c|c|}
\hline $\begin{array}{l}\text { Onchocerciasis } \\
\text { (river } \\
\text { blindness) }\end{array}$ & & Y & Y & & Y & $\begin{array}{l}\text { Reduced disease associated with deforestation and } \\
\text { loss of shade, but difficult to separate impact of wide } \\
\text { scale use of DDT (1970s); in West Africa deforestation } \\
\text { appears to have expanded the range of vector }\end{array}$ \\
\hline Echinococcosis & & Y & Y & & Y & $\begin{array}{l}\text { Land-use change in South China favours different } \\
\text { hosts in endemic area - transient increases following } \\
\text { deforestation, resurgence following reforestation; } \\
\text { increases in Europe/North America due to urbanisation } \\
\text { of foxes/landscape transformation }\end{array}$ \\
\hline Snakebite & Y & & Y & & & $\begin{array}{l}\text { Risks to forest workers; some snakes have colonized } \\
\text { suburban and urban areas, exploiting new } \\
\text { synanthropic resources (like rodents) }\end{array}$ \\
\hline Yaws & & Y & & & & $\begin{array}{l}\text { Endemic in some remote forested locations; } \\
\text { compounded by lack of healthcare access (e.g. Congo } \\
\text { Pygmies); also serve as infection reservoir for gorillas }\end{array}$ \\
\hline $\begin{array}{l}\text { Lymphatic } \\
\text { filariasis }\end{array}$ & Y & $\mathbf{P}$ & & & & $\begin{array}{l}\text { Risk to Malaysian forest workers from sub-periodic } B \text {. } \\
\text { malayi vectors and wildlife reservoirs (e.g. leaf monkeys) }\end{array}$ \\
\hline $\begin{array}{l}\text { Sleeping } \\
\text { sickness }\end{array}$ & Y & & & Y & & $\begin{array}{l}\text { Scrub clearing originally used to reduce tsetse fly } \\
\text { infestation (West Africa); significant disease risk appears } \\
\text { in SSA wet tropical forests; most cases in DR Congo }\end{array}$ \\
\hline Rabies & Y & $P$ & & & & $\begin{array}{l}\text { Deforestation impacts on host (vampire) bats increases } \\
\text { overlap with humans (likewise for bat hosts of } \\
\text { lyssavirus in Australia). Most human transmission via } \\
\text { peridomestic dogs }\end{array}$ \\
\hline
\end{tabular}




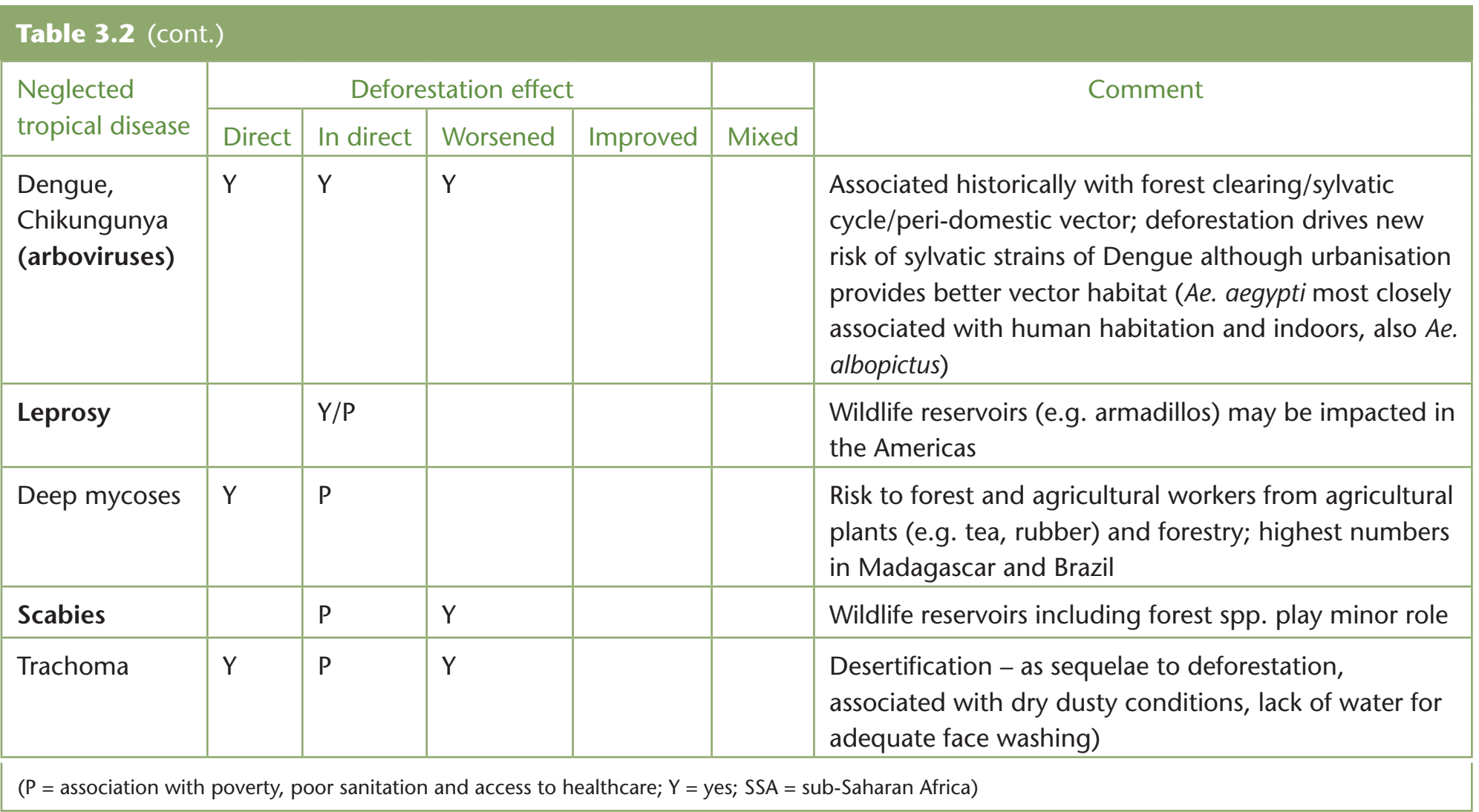


virus of global significance: currently, 36.9 million people have HIV/AIDS, two-thirds of whom live in Africa (WHO 2019a).

Forest dwellers and workers are among those who continue to be impacted: it easily spreads with extractive industries, associated with ad hoc development (with transient single males or prostitution). For those afflicted it increases demands for traditional medicines, food and income (Lopez 2008). Access to adequately funded and resourced health services with appropriate education and anti-viral medication is critical to supporting at risk and infected individuals (Targets 3.8, 3.C).

Other forest-origin diseases include Ebola, Zika, Nipah and SARS corona virus. These have also caused significant outbreaks in recent decades. Increasing human density in biodiverse areas has been associated with the emergence of these diseases (Jones et al. 2008). Contact (often indirect) between wildlife (particularly bats, rats and primates) and humans through consumption, dispersal of hosts following habitat loss, amplification following loss of predators or competitors, and exposure through deforestation, road construction and wildlife farming provide opportunities for crossspecies virus transmission. Relatively few diseases have gone on to be capable of sustained human-to-human transmission. Many others episodically spill over from their wildlife and environmental sources and are local health risks. For example, 39 of 187 arboviruses (transmitted by mosquitoes) identified in the Amazon basin during road construction can cause disease in humans (Vasconcelos et al. 2001).

Importantly, forest-origin diseases are not limited to the tropics, developing countries or even to deforestation. For example, Lyme disease is a significant risk to recreational forest users and residents in the USA and has expanded its range as a result of reforestation of previously cleared areas and altered host-pathogen dynamics. While bringing many benefits, the novel ecology of human-modified environments, including restored forests, plantations and urban parks, creates opportunity for new species combinations and disease emergence (McFarlane et al. 2012).

Predicting and preventing the next pandemic (i.e. multi-country epidemic) has been a focus of research and investment with consequences for forests, forest dwellers and the global population, as efforts are best employed to stop the spread, and possibly the emergence, at the source. Initiatives such as the US Agency for International Development Emerging Pandemic Threats programme have deployed scientists to remote forests to catalogue wildlife pathogens. Such programmes assist Target 3D to strengthen the capacity, particularly in developing countries, for early warning, risk reduction and management of national and global health risks. In regions where the burden of traditional infectious diseases remains significant, foreign investment in 
identifying pathogens that may cause future pandemics (capable of reaching developed nations) has the potential to create tensions, as well as fear. This may be sensitively and usefully navigated on a community or country basis. However, the experience of the 2013-16 Ebola pandemic in West Africa illustrates the complexity of stopping outbreaks of even identified diseases.

Ebola virus was identified in 1976 in Zaire and Sudan, with episodic outbreaks in Central Africa, associated with climatic and environmental factors, multispecies wildlife mortality and bushmeat consumption (Real et al. 2017). The virus recently spread to West Africa, potentially as habitat change and food availability impacted the ecology of the speculative bat hosts. Across West Africa in recent decades, agriculture, palm oil and other plantations have accelerated forest transformation, impacting fruit bat ecology (Wallace et al. 2014). The virus transmission that began the West African outbreak is believed to have occurred when a child played in a tree where bats roosted. However, it was the subsequent movement of infected people and the poor capacity of local health systems to perform surveillance, identification, containment or treatment of infected people that enabled the virus to spread extensively, resulting in 28616 suspected cases and 11310 deaths.

Disease regulation as a proposed ecosystem service of intact or pristine forests (Millennium Ecosystem Assessment 2005) is not broadly applicable. There is no doubt that ecological change can alter infectious diseases epidemiology, but there is no simple inverse relationship (Tucker Lima et al. 2017). Indeed, new zoonotic diseases from wildlife may ultimately cease emerging as a result of ongoing forest destruction and biodiversity loss. Sophisticated epidemiological understandings have provided targeted approaches to lowering risk, but these rarely promote forest conservation. For example, the 1998 outbreak of Nipah virus in Malaysia and Singapore, traced to contact between fruit bats (facing habitat loss and/or escaping haze from forest fires) and intensively farmed pigs, has not reoccurred, due in part to removing batattracting mango trees from pig pens (Pulliam et al. 2012). The example of Ebola illustrates the vast spatial and temporal scales over which the clearing, burning and replacement of forests may have altered the migratory patterns, population sizes and distributions of wildlife hosts. Although the capacity to address such scales is not currently available, ecosystem-based approaches to disease prevention that maximise co-benefits for people and nature are evolving (McFarlane et al. 2018).

\section{WATERBORNE DISEASES}

Waterborne diseases refer to a diverse group of pathogens including protozoa (such as giardia and cryptosporidia) and bacteria (such as typhoid, cholera and dysentery). Forests have a role to play in reducing illness and deaths from 
waterborne diseases and pollution through the protection of water catchments, reducing the impact of flooding, and in local climate regulation. Both the excess of water (e.g. flooding and faecal contamination) and its shortage (e.g. droughts and limited water for proper sanitation) can increase the risk of waterborne diseases, making climate change a concern for this group of diseases. The WHO estimates that waterborne diarrhoeal diseases were responsible for 2 million deaths in 2017, with most occurring in children under 5 (WHO 2018b) (see Target 3.2).

Natural (upper) catchments have reduced exposure to pollutants and waterborne pathogens associated with human and livestock activity. Additionally, forested watersheds generally offer higher-quality water than alternative land uses and do so at a lower cost than equivalent technology. For example, in 1997 New York City conserved the Catskill Mountains (the city's main water source) rather than install a new water filtration plant costing USD 4-6 billion, with USD 250 million a year in operating costs (Chichlinisky and Heal 1998).

The biophysical properties of forests also contribute to water quality. In Fiji, catchments cleared of their forest cover, or where riparian vegetation has been lost, show elevated incidence of waterborne infectious diseases such as typhoid and leptospirosis (Jenkins et al. 2016). Forested catchments also improve water discharge and protect against downstream flooding, although this is influenced by specific properties of the forest and catchment and the extremity of flooding (Chandler et al. 2018).

\subsubsection{Reducing Non-Communicable Diseases and Promoting Mental Health}

\section{NON-COMMUNICABLE DISEASES}

Target 3.4 calls for calls for a one-third reduction in premature mortality from non-communicable diseases (NCDs). NCDs are responsible for almost threequarters of all deaths globally, the majority of which occur in low- and middle-income countries. Six NCDs are included in the top 10 global causes of mortality (WHO 2018c): cardiovascular diseases, stroke, chronic obstructive pulmonary disease, Alzheimer's disease, respiratory cancers and Type 2 diabetes. Unhealthy diets, physical inactivity, exposure to tobacco smoke and the harmful use of alcohol are considered the most important NCD risk factors.

The global increase in overweight and obesity and its many associated health conditions, including cardiovascular diseases, diabetes and cancer, is in part connected to excess food consumption and reduced physical exercise. Unhealthy diets, particularly with high fatty and red-meat intake, as well as nutrient-poor, energy-dense diets, are increasingly common among 
poor populations in low-income settings with limited health literacy. Genetic factors make some populations especially vulnerable to diabetes. Frequently, depression, social exclusion, vulnerability and a sense of being exploited contribute to these unhealthy behaviours. The importance of forest protection for exercise and mental health are discussed below. First, we draw attention to the impact of two components of unhealthy diets on the destruction of forests.

There is a strong link between high red-meat consumption (especially beef) and the risk of death from heart disease, other NCDs and several forms of cancer (Kmietowicz 2017). Worldwide, meat production has tripled over the last four decades, increasing 20 per cent in the last decade alone. Demand for red meat, historically popular in Western countries, is growing in developing economies, in part because of its perceived status. Beef production is a major driver of deforestation, woody encroachment of savannahs and desertification. Production of livestock feed crops and pastures are the major cause of deforestation of Amazonian forests (Armenteras et al. 2017). Extensive grazing drives deforestation elsewhere, including Australia's tropical savannas, the world's largest intact savanna ecosystem. Increased cattle numbers contribute to rising quantities of the potent greenhouse gas methane as well as nitrous oxide - important issues for SDG 13 (Climate Action). Excessive beef production is deeply problematic in an era striving for sustainable development, and it has profoundly adverse health consequences (Potter 2017). Awareness of these harms has not driven per capita reduction of meat production or consumption in traditional (developed) producing countries.

Another leading cause of tropical deforestation with adverse impacts on diet is the production of palm oil. Palm oil is an affordable source of cooking oil and is valuable as a replacement for polyunsaturated oils, which have the potential to form harmful trans-fatty acids. A modest ingestion of palm oil appears to be safe; however, as a widely used ingredient of calorie-dense processed foods, it can be injurious. Indonesia and Malaysia produce 86 per cent of the world's palm oil, significantly contributing to their economies (WWF 2018). Production and continued expansion in these countries comes at a very high cost to native forests (and Indigenous peoples), along with significant harms to health.

In contrast, conserving forests as a source of nutrient rich foods is important for associated Indigenous people and subsistence farmers (Ickowitz et al. 2016). Micronutrient deficiencies affect two billion people worldwide, predisposing them to disease and poor cognitive development. For forest-associated groups, there can be a cost-effective synergy of healthy people, food harvesting and stewarded forests. This should be valued against the destruction of forests for unhealthy global diets, hunger reduction (SDG 2) and the production of greenhouse gasses (SDG 13). 


\section{MENTAL HEALTH}

The WHO reports that 14 per cent of the global burden of disease is attributed to mental health disorders, with 75 per cent of affected people from low-income countries (WHO 2018c). The role of forest loss in these figures is not known. However, the stimulation and stresses of urban life - more than half of the global population live in urban areas - has generated interest in the consequences of nature deprivation, a situation forewarned in the 1950s by René Dubos, one of the founders of ecological public health at the planetary scale. There are also impacts for Indigenous and other non-urban forest people. For many, the landscapes of personal and community significance have disappeared, often rapidly and recently. Solastalgia - the psychic or existential stress caused by environmental change (Albrecht et al. 2007) - can be profound and amplified by disempowerment, marginalisation, the loss of religious or cultural sites and identity.

Most of the research and practice concerning natural environments and mental (and physical) health is undertaken in urban and developed settings. That increased exposure to high-quality green and blue space (tree-lined streets, parks, gardens and water views) is beneficial to physical and mental health is intuitively attractive to all who value nature. However, as with the disease regulation theory, the idea that exposure to green space is automatically beneficial to health is simplistic. Many of the world's poorest and least healthy populations, including Indigenous and other populations living in or around forests, are exposed to considerably more green space than the average urban inhabitant, yet have poor physical health. While absence of nature contact may be harmful, abundant exposure does not fully offset other risk factors for ill health.

For most of the global population now classed as urban dwellers, there is evidence of positive effects of visiting or even having green space in one's neighbourhood, not just for the wealthier in leafy suburbs. Gains may be greatest for groups otherwise deprived of access (Taylor et al. 2015). There is growing evidence that biological diversity is responsible for some of the reported positive effect (Aerts et al. 2018). Biological mechanisms account for some of the reported health benefits. For example, in addition to the physiological contributions to cardiovascular health from increased exercise, cleaner air and less noise (Donovan et al. 2015), there is growing evidence that the human microbiome may be enhanced by exposure to biodiverse environments, including forests (Prescott et al. 2016). Immune function and other objective biomarkers for health, such as cortisol levels and blood pressure, may also be improved (Rook 2013). Some studies have found that even brief interactions with nature can produce marked increases in cognitive function (Berman et al. 2008). 
The distribution of green space across cities is now considered a source of health inequity, recognised broadly, for example, by the European Environment Agency and as a specific target within SDG 11 (Sustainable Cities and Communities). Box 3.1 discusses this in more detail.

\section{Box 3.1 Urban Forests and Health}

The term 'urban forest' has been in use since the 1970s and includes all trees within a metropolitan boundary. There is growing recognition of urban forests' importance to health and, more recently, also its ecological value.

Health benefits include reduced flows and nutrients in storm water, pollution control, shade and urban heat island reduction, by $4-5^{\circ} \mathrm{C}$ in some settings (Livesley et al. 2016) - of growing importance under climate change. Trees reduce air pollution due to cars, industry and coal burning. All tree species capture PM10 (particulate matter up to 10 microns in diameter), but some are much more efficient than others (Manes et al. 2016, Yang et al. 2005). Trees can store and remove carbon and, depending on type and form, reduce particulate matter by 7-24 per cent. The urban forest also provides opportunity for residents to have some contact with nature and to garner its benefits, such as reducing developmental issues in children and behavioural issues in young adults, improving mental health more generally, and as a backdrop for exercise (see Target 3.4). Improved recovery time in patients with natural views or direct exposure to nature has led to the purposeful planting of trees around hospitals and medical centres (CSH 2018). Interestingly, exposure to virtual forests (and nature) is reported to have significant impact on cognitive function in people with dementia (Moyle et al. 2017).

However, some trees (such as poplars) emit volatile organic compounds that interact with car exhausts and increase the concentration of ground-level ozone, particularly during heatwaves (Willis and Petrokofsky 2017). Trees provide habitat for urban animals, including birds, squirrels, possums, monkeys and bats, providing many valuable benefits, though some carry infectious diseases, e.g. West Nile virus, Lyme disease, Hendra virus (McFarlane et al. 2012). Another drawback is hay fever, which can be debilitating, from allergenic plants, including trees with high pollen counts. Increased risks of fires in towns and cities due to climate change can be aggravated by urban forests.

Nevertheless, urban forest design, sometimes referred to as green infrastructure, is potentially a significant factor - and is increasingly recognised - in human health and ecosystem service protection and conservation (Kowarik and von der Lippe 2018). 
Outside cities, there is further evidence of positive effects (Maller et al. 2006). In South Korea - a highly industrialised, urbanised nation with a high rate of suicide - the therapeutic exposure to national parks is now being vigorously promoted. In Japan, the term shinrin-yoku refers to the practice of 'forest bathing' for well-being, with growing evidence that this is beneficial. The positive benefits of spending time in wilderness to deal with death, including one's own, have been investigated in Canada. New Zealand has pioneered 'green prescriptions' that recommend physical activity, a concept that has grown to include the added benefits of exercising in nature. The Healthy Parks Healthy People (HPHP) movement, particularly active in Australia and the USA, promotes the benefits of park use to increase social well-being and reduce NCDs. HPHP has also pioneered some significant cross-sectoral relationships between government health and environment sectors.

In summary, there is persuasive evidence of benefits to mental and physical health from increased exposure to forests, at least for those for whom it is not a daily event. These benefits are likely greatest for those living in urban areas and whose basic health needs (nutrition, housing and an income allowing dignity and physical security) are largely met (Tomita et al. 2017).

\section{MENTAL AND PHYSICAL WELL-BEING BEYOND THE URBAN FOREST}

The suffering, especially mental, when Indigenous and other peoples lose their forests has been relentless for centuries and continues today, although poorly documented and almost universally overlooked by the colonising groups. An authentic commitment to reduce mental health suffering resulting from the forest-conversion actions of others requires protecting forests and the rights of their traditional custodians (e.g. West Papuans and the Congo Pygmies; Ohenjo et al. 2006). Prohibition of forest use, including for culturally important products such as bushmeat or medicine, regardless of the abundance of non-traditional alternatives, may cause psychological unrest and affect well-being (e.g. various Congo basin forest peoples; Dounias and Ichikawa 2017).

Protecting the eudemonic well-being of many groups and populations not resident in forests is still deeply grounded in forest protection. Collective well-being is reflected, for example, in respect for sacred sites or ancestors and the opportunity to pass on biodiverse natural resources and customary tenure rights to future generations, in turn protecting well-being, identity and kinship (Fritz-Vietta 2016). An estimated 5-8 per cent of global forests are considered to be sacred. Protecting these forests has profound consequences for people as well as conservation. For example, monk-led community conservation of 18000 ha of rare lowland evergreen forest in Northern Cambodia, motivated by reverence for the example and teaching of Buddha, has been 
focal in post-Khmer Rouge community recovery (ARC 2010). In summary, forest conservation promotes mental well-being in diverse ways.

\section{FORESTRY ACCIDENTS}

Statistics on forestry accidents are difficult to obtain and are sparsely reported outside developed nations. Available reliable data suggest that forestry-related work is extremely hazardous. Occupational health and safety for many who work in forestry is poorly regulated, particularly for those who work informally. Tree felling is the deadliest occupation in forestry; in developing countries, chainsaws may be involved in nearly half of all forestry accidents. Other reported issues include chemical exposure (e.g. pesticides), hearing loss, heatand cold-related diseases, repetitive stress syndromes and musculoskeletal trauma (Garland 2018). Sedentary machine operators have increased risk of diabetes and obesity. Addressing SDG 3 targets would benefit these groups and those exposed to hazardous chemicals. Halving road traffic accidents globally (Target 3.6) would also benefit forestry workers.

\subsubsection{Reproductive Health and Family Planning}

Target 3.7 calls for universal access to sexual and reproductive healthcare services, including family planning, information and education, and the integration of reproductive health into national strategies and programmes. Although this target encompasses a range of important issues, its most relevant aspect to forests (and the other SDGs) is to promote access to contraception and thus to slow population growth (Starbird et al. 2016).

There is abundant evidence that rapid population growth hinders economic development, intensifies resource insecurities and environmental damage, and fuels conflicts (Bongaarts 2016, Butler and Higgs 2018, Husain et al. 2016, Population Institute 2015). No country has been able to advance from least-developed status while fertility remains above four children per woman, unless (and only for as long as) it has vast oil or other natural-resource income. Generally, economic development has only taken off after fertility falls well below three children, being highest in countries with below-replacement fertility (O'Sullivan 2017). Successful voluntary family planning programmes preceded the economic growth of the East Asian tiger economies.

Forest-dependent people, including Indigenous minority groups, tend to have higher fertility than their national averages and are disadvantaged in access to family planning. This impacts family finances, resource security and the health and well-being of women and children, as well as demands on forests. Smaller families and wider child spacing mean more investment per child. Universal access to family planning would help close the development gap between forest dwellers and urbanised communities. 
Even in developed countries, more than 40 per cent of pregnancies are unintended. Access to contraception and the outcomes of unwanted pregnancies are problematic for many (Foster et al. 2018), and each birth draws more heavily on Earth's natural resources (Wynes and Nicholas 2017).

Population growth is a major driver of forest loss. The Food and Agriculture Organisation of the UN (FAO 2016) reports a strong correlation across regions between forest loss and increase in rural population. Traditional swidden agriculture relies on long forest fallows, but as fallow periods shorten under population pressure, forest remnants shrink and become degraded before being permanently cleared. Commodity-driven deforestation is reported as the largest category of forest loss (Curtis et al. 2018) but small-holder plots are also cleared for 'commodity agriculture', often enabled by nearby largescale commercial plantations or new roads through forests. In Africa, subsistence agriculture is the dominant cause of forest conversion (Curtis et al. 2018). Burgeoning population and affluence in emerging economies increases commodity demand; this is also driven by affluent populations globally.

The IPCC-led ${ }^{1}$ modelling of future climate change scenarios found that limiting warming to $2^{\circ} \mathrm{C}$ is only feasible with population growth much lower than current UN projections. A major stumbling block is agricultural demand, making further deforestation unavoidable (Riahi et al. 2017). The World Resources Institute estimates that achieving replacement-level fertility (about 2.1 children per woman) by 2050 could save an area of forest the size of Germany, seeing this as 'a multi-win solution to humanitarian, economic and environmental challenges, and an important item on the menu for a sustainable food future' (Searchinger et al. 2013: 2).

How much population-growth reduction may be achieved by the SDGs is complex and uncertain. Since the 1980s, the 'demographic-economic' rationale for slowing population growth, once a central pillar of the development agenda that influenced many norms, has been diluted, largely replaced by reproductive health services, emphasising only the 'reproductive health and rights' rationale for family planning, undertaken in many developing countries by poorly funded health ministries and some NGOs (Bongaarts 2016). The reproductive health and rights framing is today missing two vital ingredients: political will, stemming from the conviction that high population growth threatens economic development, and a focus on motivating people to want smaller families and to use contraception. Together, these elements can reduce the fatalistic acceptance of large families and gain support for family planning even in patriarchal societies.

\footnotetext{
${ }^{1}$ Intergovernmental Panel on Climate Change.
} 
There are tentative signs of rekindled interest in the demographic rationale. Integrated development projects, under the 'population, health and environment' (PHE) model (Oglethorpe et al. 2008), are gaining recognition for achieving behavioural changes more rapidly than single-sector interventions, e.g. in environmental management, health and sanitation practices and diversified livelihoods, as well as those embracing smaller families and women's access to education and employment (see Box 3.2).

\section{Box 3.2 Conservation, Community Health, Family Planning and Livelihoods}

Conservation initiatives have recognised the importance of supporting the health and livelihoods of local populations in high-conservation-value areas for some time (Ancrenaz et al. 2007). This is strongly supported within organisations such as the International Union for Conservation of Nature (IUCN), the UN Development Programme (UNDP) and the Word Wide Fund for Nature (WWF), and it takes many forms.

In North Kayong, Kalimantan, Indonesia, the Alam Sehat Lestari (ASRI) clinic provides villagers with the most extensive healthcare services in the area and incentives to stop them from logging in the adjacent Gunung Palung National Park, such as 70 per cent discounts on medical fees. The clinic represents an alternative to health services provided by forestry companies. Patients who cannot afford medical fees, and so might otherwise resort to illegal logging, can choose to pay with various non-cash options, including native seedlings or labour. ASRI replants forests and trains ex-loggers to farm and run alternative businesses through a chainsaw buy-back scheme. Since inception, the number of logging households has decreased by 89 per cent, primary forest loss has stabilised and infant mortality has declined from 3.4 to 1.1 deaths per 100 households. This model is now being replicated elsewhere on the island of Borneo (Webb et al. 2018).

The Bwindi Impenetrable National Park in Uganda is home to about half of the world's remaining mountain gorillas. Conservation Through Public Health (CTPH) was initially established to address the transmission of diseases between gorillas, livestock and human populations. As it quickly became apparent that diversified livelihood assistance was needed to reduce park incursions, the project added livestock and microfinance programmes. It soon added family planning, realising that many parents were having more children than they wanted, while population growth countered conservation efforts. The project demonstrated strong synergies in cross-sectoral work, as the trust built through one area made communities more receptive to information in other sectors. Health and livelihood activities built support for conservation goals; ecological 
Box 3.2 (cont.)

understanding generated enthusiasm for family planning. Contraception use increased twelvefold, to more than 60 per cent of women. Gorilla numbers have subsequently increased (Wilson Center 2013).

The model adopted by CTPH is the PHE approach (Oglethorpe et al. 2008). PHE projects recognise that tackling population growth is crucial for the long-term sustainability of environment and development interventions. By engaging with communities on their own priorities and enabling them to draw linkages between their livelihoods, resource base, family size and ability to educate and provide for children, they are motivated and empowered to overcome cultural barriers to change. PHE projects have particularly built male support for family planning and female participation in natural resource management. Since the early 2000s, PHE projects have gained increasing recognition. Many established projects, such as Ethiopia's Ethio Wetlands and Natural Resources Association and Papua New Guinea's Tree Kangaroo Conservation Programme, have adopted PHE approaches to enhance their impact. CTPH is a role model for several other PHE projects and a successful advocate for PHE to be recognised and scaled up through government agencies.

\subsubsection{Universal Health Coverage and Affordable Essential Medicines}

Target 3.8 strives to achieve universal health coverage, including financial risk protection, access to quality essential healthcare services and access to safe, effective, good-quality and affordable essential medicines and vaccines. Seeking this goal has potential beneficial effects for forests and people. Universal health coverage would benefit forest dwellers and forests since few options exist in remote forest locations to access modern healthcare or pay for it - other than through illegal timber felling, hunting bushmeat or illegal pet or medicinal plant trade. Many conservation groups recognise this relationship (Box 3.2). Additionally, through enhanced protection of genetic resources, as proposed by the Nagoya Protocol (Convention on Biological Diversity), the vast traditionally used and potential medical resources provided by forests may receive better protection.

\section{PROTECTING THE NATURAL PHARMACOPOEIA}

Traditional knowledge derived from a close relationship to nature is extremely important for pharmacological resources locally and globally (Fabricant and Farnsworth 2001). Many drugs are derived from compounds found in plants, often identified via their traditional use (Chivian and Bernstein 2008). 
Conservative estimates of flowering plant species worldwide is 250 000; there is likely an abundance of drugs yet to be discovered.

Preserving and maintaining biodiversity and associated traditional knowledge is extremely important for the cultural well-being of local communities. The WHO estimates that up to 80 per cent of developing country populations rely, in part, on traditional medicine for their primary healthcare needs (WHO 2015). In many settings, traditional health systems are culturally preferred, and often based on complex social and spiritual relationships and directly dependent on natural resources. However, traditional knowledge and associated pharmacological knowledge is vanishing very quickly (Reyes-García et al. 2013). So too are many therapeutic plant and fungal species, although intensive efforts are being made to identify species with potential therapeutic value.

Fulfilling Target 3.8 is likely to protect forest ecosystem services in two ways. The first benefit is the protection of unidentified 'natural pharmacopeia': ethically exploring, cataloguing and protecting traditional knowledge about natural pharmaceutical properties can help identify useful remedies. In parallel, protecting as many species as possible, particularly in their traditional settings (as stated in the 2010 Nagoya Protocol, also linked to SDG 15, Life on Land), can ensure this knowledge can be tested and applied if found beneficial. This can be summarised as protecting the unidentified 'natural pharmacopeia'.

The second benefit will flow from a more thorough investigation of the possible 'false pharmacopeia', referring particularly to animal parts, but also some plants and fungi, that have zero, marginal or even adverse health benefits, yet are harvested from the wild (especially for consumption by large urban markets) and have significant harmful ecological effects despite their cultural importance. Numerous wildlife species, some inhabiting forests, have been pursued to (near) extinction for their alleged pharmaceutical benefits, including charismatic mammals such as the rhinoceros, snow leopard and tiger, as well as the humble pangolin (Byard 2016). Evidence of therapeutic benefits for many traditional remedies involving animal parts is extremely limited.

\subsubsection{Improving the Quality of Air, Water and Soil}

Target 3.9 calls for a substantial reduction in the number of deaths and illnesses from hazardous chemicals and air, water and soil pollution and contamination. There is broad recognition of the health burden of air pollution, particularly from fossil fuels and petrochemicals, as well as its disproportionate 
impact on the poor (Landrigan et al. 2018). This, and to a lesser extent water and soil pollution control, has several direct implications for forests. Exposure to hazardous chemicals, particularly pesticides, is a recognised risk for forestry workers (Garland 2018).

\section{AIR POLLUTION}

Air pollution is chiefly from the combustion either of fossil fuels such as coal and petroleum or of biomass. The latter include forest fires, a burn following clearing of forests, and/or the burning of organic-rich forest soils (peats). The frequency of peat fires appears to be increasing due to climate change (Seidl et al. 2017), via intensifying drought, heat, stronger winds and increased dry lightning storms. Other forms of biomass combustion relate to burning as an agricultural practice, as a form of land management and as a household fuel.

\section{HOUSEHOLD-ASSOCIATED AIR POLLUTION}

Biomass, including dung, crop residues and wood, provide the main cooking fuel for at least 2.8 billion people (Bruce et al. 2015). Much of this is combusted inside dwellings with poor ventilation, contributing to high rates of respiratory and other diseases. Increasingly referred to as householdassociated air pollution (Goldemberg et al. 2018), smoke-induced diseases are responsible for the premature death of 4.3 million people annually, with women and young children most affected (Bruce et al. 2015). An estimated 500000 children under 5 die each year of preventable and treatable respiratory conditions, worsened by household air pollution, undernutrition and inadequate health care (Langbein 2017). Considerable effort over decades has been directed to developing low-cost, safer cooking stoves, but with variable success (Goldemberg et al. 2018). Furthermore, gathering fuelwood can have significant environmental impact, in some areas driving desertification (Masera et al. 2015).

Any successful attempt to attain SDG 3.9 needs to promote the replacement of forest products with forms of energy less damaging to health and the environment. This may be possible through large-scale electrification using wind and solar power (or with hydroelectricity, as in the case of Ecuador); yet, in most settings the cost of clean electrical power (e.g. solar, wind or hydro), though increasingly plausible for lighting, is still too high to make this a likely prospect for populations living away from centralised, reliable energy supplies. Gas is being increasingly used, especially in Brazil and India; though far better for health, it still results in significant carbon emissions and is unaffordable for most (Goldemberg et al. 2018). The flooding of forests and farmland to produce hydroelectricity has been a source of 
controversy in many areas, particularly when benefits are realised at a distance from the land lost.

\section{RESPIRATORY DISEASE ASSOCIATED WITH FORESTRY}

Specific hazards associated with wood processing and manufacturing industries (e.g. inhaled sawdust, pulp and mould) can lead to a range of bacterial, fungal and airborne endotoxin infections, generating respiratory disorders such as wood workers' lung and hypersensitivity pneumonitis (Adhikari et al. 2015, Sforza and Marinou 2017). These conditions can affect not only workers but also people living in the vicinity of these industries.

\section{FOREST FIRES AND TRANSNATIONAL AIR POLLUTION}

In some parts of the world, especially Southeast Asia, the Amazon and subSaharan Africa, the deliberate, seasonal burning of forests, mainly to promote agriculture and plantations, creates a substantial health hazard (Johnston et al. 2012). For example, forest burning during the dry season in Kalimantan and Sumatra (Indonesia) contributes regularly to dangerous levels of air pollution. In 2015, as climatic conditions resulted in drought and greatly intensified fire activity in the region, persistent, hazardous levels of smoke pollution (haze) resulted in an estimated 100000 deaths across Indonesia, Malaysia and Singapore - more than double those from previous reported events in 1997 and 2006 (Koplitz et al. 2016). Such hazardous conditions can cause schools and many workplaces to close, grounding of air traffic and residents being encouraged to stay indoors. Not all residents can gain respite indoors or have means to evacuate. In 2002, several $\mathrm{ASEAN}^{2}$ nations passed a Transboundary Haze Pollution Act that financially penalises companies for smoke-haze activities beyond the borders of individual countries. Since 2017, sustainability certification of forest industries in Indonesia has significantly reduced deforestation and associated fires (Carlson et al. 2017). Similar concerns over the quartet of forest fires, particulate matter pollution, respiratory disease and carbon emissions exist in the Amazon basin.

\section{FORESTS, WATER AND SOIL}

All measures that protect agricultural productivity and ensure food and water safety have significant benefits for health. Forests enhance soil biodiversity and organic matter recycling; limit desiccation, erosion and dryland salinity; and promote pest control by providing shelter for pest-predators. The capacity of forests to reduce soil contamination from pollutants may be significant, yet it remains under-researched. Phytoremediation of contaminated

\footnotetext{
${ }^{2}$ Association of South East Asian Nations
} 
land (including heavy metals and radioactive material) does utilise some tree species, as well as grassland and forbs. Large, uncontrolled forest fires can result in water pollution that reduces the quality of water emerging from forests.

\section{CLIMATE CHANGE, FORESTS AND HEALTH}

Climate change primarily results from the accumulation of heat-trapping gases in the atmosphere. It can thus be conceptualised as a form of air pollution, worsened not only by the transfer of carbon in fossil fuels but also from biomass (including in the soil) and, increasingly, from tundra and peat to the atmosphere (and ocean). Its health effects are protean, but still largely in the future. Heat stress for outdoor labourers, already significant where conditions and underlying health are poor, will amplify in impact, affecting many people in and near forests engaged in such labour. Further impacts, including direct trauma, are anticipated from heatwaves from other forms of extreme events, including rising sea levels, storm surges, droughts, flooding, fires and high winds.

Addressing Target 3.4 by reducing forest destruction, including fires, would have the co-benefit of reducing carbon emissions (not only of overlying vegetation but in some cases underlying peat), which can be of global significance during El Niño years (Page et al. 2002). Emissions from peat oxidation resulting from water-table lowering add to the carbon burden. In Southeast Asia, forest and swamp conversion for plantations and other agriculture means that a major carbon sink is now a carbon source (Miettinen et al. 2017). Reducing emissions from deforestation and forest degradation, and reducing health impacts of climate change, are already important elements of UN climate policy. Additionally, the potential for coastal mangrove forests to provide protection from coastal storm surges is now contributing to their conservation (Feller et al. 2017), and the ability of the urban forest to reduce a city's temperature is increasing recognition of the value of trees (Box 3.1). Action to avoid tipping globally important forest areas into other, postclearance ecological states additionally protects future carbon sequestration (Miettinen et al. 2017).

Other impacts on health through climate change are manifold: global food price increases, local crop failures (to which subsistence populations are particularly vulnerable), reduced labour productivity and alterations in the epidemiology of vector-borne and other infectious diseases. In the long run, perhaps most importantly, the highly indirect, politically mediated 'tertiary' effects from famine, economic disruption, population displacement and conflict will prove most harmful (Butler 2014). 


\subsection{Summary and Recommendations}

Table 3.3 summarises the impacts of implementing SDG 3 targets on forests and forest-dwelling people. Benefits to forest people assume targets will be pursued through a social justice lens (poor-preferencing) or at least neutrality, so that, at the minimum, forest people are not disadvantaged by development.

In theory, most SDG 3 targets can be improved in ways that protect forests, as discussed in this chapter. In reality, the pathways are predicated on increased economic growth (and possibly population) and that is likely to cause harm to forests, rather than be beneficial or neutral. Finally, we conceptualised the links between forests and population health at three scales (Figure 3.1) and summarise the findings of this chapter in this way.

\begin{tabular}{|c|c|c|c|}
\hline \multicolumn{2}{|r|}{ SDG 3 targets } & \multicolumn{2}{|c|}{ Impacts } \\
\hline & & On forests & On people \\
\hline 1 & Reduced maternal mortality & & \\
\hline 2 & Reduced neonatal and under-5 mortality & & \\
\hline 3 & Communicable disease control & & \\
\hline 4 & $\begin{array}{l}\text { Reduction of non-communicable diseases } \\
\text { and mental health problems }\end{array}$ & & \\
\hline 5 & Prevent substance abuse & & \\
\hline 6 & Road traffic accidents & & \\
\hline 7 & Reproductive health & & \\
\hline 8 & Universal health coverage & & \\
\hline 9 & Pollution and hazardous chemical control & & \\
\hline A & Tobacco control & & \\
\hline B & Improved vaccines and medicine access & & \\
\hline C & Health financing and recruitment & & \\
\hline $\mathrm{D}$ & Early risk warning & & \\
\hline
\end{tabular}


HOW ATTAINING SDG 3 COULD AFFECT FORESTS AND POPULATIONS DEPENDENT ON FORESTS

- Improving health and well-being of Indigenous and other forest-adjacent communities can positively impact forests where these groups play a crucial role in forest stewardship, including sustainable management of natural resources.

- Economic development of forested areas that ignores harm to Indigenous and local people and the ecosystem services on which they rely will almost inevitably decrease their health and well-being.

- Access to family planning, health education, investment in clean water and sanitation, alternatives to wood biomassfuel and control of large forest fires have co-benefits to people and forests (Targets 3.7, 3.8, 3.9, 3.C and other SDGs).

- Achieving universal health coverage has an important role to play in making healthcare affordable and reducing pressure on forests from (catastrophic) health expenditure (Target 3.8). Health workers should be aware of potential negative consequences of development (such as disempowerment and its mental health consequences; sedentary lifestyles; nutrient-poor and unhealthy food; tobacco, alcohol and other substances; commercial sex trade) (Targets 3.3, 3.4, 3.5, 3.7, 3.8, 3.C).

- Traditional medical systems should be integrated into contemporary healthcare to ensure the most culturally appropriate treatment for Indigenous peoples. Medical and other healthcare personnel should collaborate with traditional healers to provide more efficient services and gain better understanding of traditional practices necessary for appropriate healthcare. Preservation of cultural and ecological knowledge is also valued by pharmacological research (Target 3.8).

- Research and surveillance for emerging diseases and health risks at the forest interface is best coupled with support to address existing disease burdens, reducing risks and improving health literacy and capacity (Targets 3.3, 3.D).

HOW ATTAINING SDG 3 COULD AFFECT FORESTS AND THOSE WHOSE COMMERCIAL LIVELIHOODS ARE DEPENDENT ON FORESTS

- Reduction of hazardous chemicals and air, water and soil pollution and contamination will improve the health of forestry workers and adjacent communities (Target 3.9).

- The work-related health problems of Indigenous and traditional people and other people engaged in unorganised sectors (e.g. leaf plate-making, 
handicraft) are largely unreported and not specifically identified within SDG 3. Work-related injuries and even mortality resulting from forestry is important but also largely unreported.

- Control of vast forest and peat fires and the resulting haze and transnational air pollution and associated loss of life is relevant to local as well as distant populations; efforts to strengthen the capacity to reduce and manage global health risks include such fire control (Target 3.D).

- Infectious diseases emerging from disturbed forests or from the hunting or dispersal of vectors and wildlife hosts may be a particular risk to forestry workers (e.g. malaria) or plantation farmers (e.g. Chagas disease). Surveillance and management of forests to limit infectious disease risks requires further research, but includes positive and negative outcomes for forests and forest people (Targets 3.3, 3.D).

- The target to reduce non-communicable diseases, where linked to dietary commodities associated with health risks such as red meat or palm oil, may challenge extensive forest clearing for their production (Target 3.4).

\section{HOW ATTAINING SDG 3 COULD AFFECT FORESTS AND REGIONALLY DEPENDENT} POPULATIONS

- Recognition that natural forest catchments are cost-effective in addressing water pollution and quality should encourage their protection and reestablishment (Target 3.9).

- Urban demand for bushmeat, bush medicines and some timbers is driving unsustainable pressure on forests. Alternatives need to be identified and promoted.

\section{HOW ATTAINING SDG 3 COULD AFFECT FOREST AND GLOBAL AND URBAN POPULATION}

- Climate change is not singled out as a global health risk in SDG 3; however, we note not only that this exists, but also that reducing forest destruction has the co-benefit of maintaining carbon sequestration and local climate regulation. International cooperation is required to address this risk (Target 3.9).

- As with all scales described here, universal access to family planning has an important role in reducing human pressure on forests (and natural resources). This is relevant not only for populations in forested areas, but also for those at any distance where consumption drives demand for forest products (Target 3.7).

- Cultural and spiritual ecosystem services of forests contribute to the wellbeing of many people who may rarely (if ever) visit them. Recreational 
forest users may gain additional mental, physical and immunological benefits from forests. This is an area that warrants further research (Target 3.4).

- The urban forest is increasingly valued and developed for the mental, social and physical well-being it can provide urban dwellers. Linking improvements in health with urban-forest use and proximity could contribute to forest maintenance and expansion more generally (Target 3.4).

\subsection{Conclusions}

This chapter has reviewed many ways in which genuine attempts to attain the targets associated with SDG 3 can protect forests, forest ecosystem services and the people who rely on them. It has discussed the close relationship between many aspects of health and forests, not only for Indigenous and other peoples directly dependent on forest benefits but, less directly, for the global population. Forests play an important part in maintaining earth systems, and their erosion has potentially negative and catastrophic consequences for the health and well-being of the global human population, particularly those already vulnerable. Adjustments to our definitions of health, protection of its social and ecological determinants and recognition of planetary limits will contribute to global health and, in so doing, will safeguard forests.

This chapter has identified the cognitive dissonance evident in the SDGs that seek to expand economic growth (as conventionally defined) yet protect natural capital, including forests. The chapter has also discussed how a failure to improve reproductive health, especially by inadequate provision of family planning services and other influences on fertility, threatens forests and forest populations and will also threaten the achievement of many other SDGs. A way forward may be to foster the understanding, among those with more political and economic power, that their health and well-being will be promoted by more biosensitive activities, such as a diet less reliant on animal products, less wasteful consumption and more contact with nature. These principles also apply for many people in the global aspirational class, and give homage to those Indigenous and traditional groups that still live by these values.

\section{References}

Adhikari, A., Sahu, S., Bandyopadhyay, A., Blanc, P. D. and Moitra, S. 2015. Fungal contamination of the respiratory tract and associated respiratory impairment among sawmill workers in India. ERJ Open Research 1:00023-2015. 
Aerts, R., Honnay, O. and Van Nieuwenhuyse, A. 2018. Biodiversity and human health: Mechanisms and evidence of the positive health effects of diversity in nature and green spaces. British Medical Bulletin 127:5-22.

Albrecht, G., Sartore, G. M., Connor, L. et al. 2007. Solastalgia: The distress caused by environmental change. Australasian Psychiatry 15:S95-S98.

Ancrenaz, M., Dabek, L. and O'Neil, S. 2007. The costs of exclusion: Recognising a role for local communities in biodiversity conservation. PLOS Biology 5:e289.

ARC 2018. Monks' community forest in Cambodia wins prestigious Equator Prize. UK: Alliance of Religions and Conservation. Available at: www.arcworld.org/news.asp? pageID=412 (Accessed 4 February 2019).

Armenteras, D., Espelta, J., Rodríguez, N. and Retana, J. 2017. Deforestation dynamics and drivers in different forest types in Latin America: Three decades of studies (1980-2010). Global Environmental Change 46:139-147.

Barber, B. E., Rajahram, G. S., Grigg, M. J., William, T. and Anstey, N. M. 2017. World malaria report: Time to acknowledge Plasmodium knowlesi malaria. Malaria Journal 16:135.

Bauhoff, S. and Busch, J. 2018. Does deforestation increase malaria prevalence? Evidence from satellite data and health surveys. Working Paper 480. Washington, DC: Center for Global Development.

Berman, M., Jonides, J. and Kaplan, S. 2008. The cognitive benefits of interacting with nature. Psychological Science 19:1207-12.

Bongaarts, J. 2016. Development: Slow down population growth. Nature 530:409-12.

Bruce, N., Pope, D., Rehfuess, E. et al. 2015. WHO indoor air quality guidelines on household fuel combustion: Strategy implications of new evidence on interventions and exposure-risk functions. Atmospheric Environment 106:451-457.

Butler, C., Chambers, R., Chopra, K. et al. 2003. Ecosystems and human well-being. In Ecosystems and human well-being. A framework for assessment. Millennium Ecosystem Assessment. Washington DC: Island Press, pp. 71-84.

Butler, C. D. (ed.) 2014. Climate change and global health, Wallingford: CABI.

Butler, C. and Higgs, K. 2018. Health, population, limits and the decline of nature. In Marsden, T. (ed.) The Sage Handbook of Nature. London: Sage Publications, pp. 1142-49.

Byard, R. W. 2016. Traditional medicines and species extinction: Another side to forensic wildlife investigation. Forensic Science, Medicine, and Pathology 12:125.

Carlson, K. M., Heilmayr, R., Gibbs, H. K. et al. 2017. Effect of oil palm sustainability certification on deforestation and fire in Indonesia. Proceedings of the National Academy of Sciences 115(1):121-6.

Chandler, K., Stevens, C., Binley, A. and Keith, A. 2018. Influence of tree species and forest land use on soil hydraulic conductivity and implications for surface runoff generation. Geoderma 310:120-7.

Chaves, L., Conn, J. E., López, R. V. and Sallum, M. A. 2018. Abundance of impacted forest patches less than $5 \mathrm{~km}^{2}$ is a key driver of the incidence of malaria in Amazonian Brazil. Scientific Reports 8:7077. 
Chichlinisky, G. and Heal, G. 1998. Economic returns from the biosphere. Nature 391:629-30.

Chivian, E. and Bernstein, A. (eds.) 2008. Sustaining life. How human health depends on biodiversity. Oxford: Oxford University Press.

CSH (Centre for Sustainable Healthcare) 2018. The NHS Forest. Oxford. Available at: https:// sustainablehealthcare.org.uk/what-we-do/green-space/nhs-forest.

Curtis, P. G., Slay, C. M., Harris, N. L., Tyukavina, A. and Hansen, M. C. 2018. Classifying drivers of global forest loss. Science 361:1108-11.

Donovan, G. H., Michael, Y. L., Gatziolis, D., Prestemon, J. P. and Whitsel, E. A. 2015. Is tree loss associated with cardiovascular-disease risk in the Women's Health Initiative? A natural experiment. Health \& Place 36:1-7.

Dounias, E. and Ichikawa, M. 2017. Seasonal bushmeat hunger in Congo basin. EcoHealth 14:575-90.

Fabricant, D. S. and Farnsworth, N. R. 2001. The value of plants used in traditional medicine for drug discovery. Environmental Health Perspectives 109:69.

FAO 2016. State of the world's forests 2016. Forests and agriculture: Land-use challenges and opportunities. Rome. Available at: www.fao.org/publications/sofo/en/ (Accessed 4 February 2019).

Feller, I. C., Friess, D. A., Krauss, K. W. and Lewis, R. R. 2017. The state of the world's mangroves in the 21st century under climate change. Hydrobiologia 803:1-12.

Foster, D. G., Biggs, M. A., Ralph, L. et al. 2018. Socioeconomic outcomes of women who receive and women who are denied wanted abortions in the United States. American Journal of Public Health 108:407-13.

Fritz-Vietta, N. V. M. 2016. What can forest values tell us about human well-being? Insights from two biosphere reserves in Madagascar. Landscape and Planning 147:28-37.

Garland, J. J. 2018. Accident reporting and analysis in forestry: guidance on increasing the safety of forest work. Forestry Working Paper No. 2. Rome: FAO.

Goldemberg, J., Martinez-Gomez, J., Sagar, A. and Smith, K. R. 2018. Household air pollution, health, and climate change: Cleaning the air. Environmental Research Letters 13:030201.

Government of South Australia and WHO 2017. Progressing the Sustainable Development Goals through Health in All Policies: Case studies from around the world. Adelaide: Government of South Australia.

Guerra, C. A., Snow, R. W. and Hay, S. I. 2006. A global assessment of closed forests, deforestation and malaria risk. Annals of Tropical Medicine and Parasitology 100:189-204.

Huber, M., Knottnerus, J. A., Green, L. et al. 2011. How should we define health? BMJ:343:d4163.

Husain, I., Patierno, K., Zosa-Feranil, I. and Smith, R. 2016. Fostering economic growth equity and resilience in sub-Saharan Africa: The role of family planning. Washington DC: US Agency for International Development.

Ickowitz, A., Rowland, D., Powell, B., Agus Salim, M. and Sunderland, T. 2016. Forests, trees and micronutrient rich food consumption in Indonesia. PLOS ONE 11:e0154139.

Jenkins, A. P., Jupiter, S., Mueller, U. et al. 2016. Health at the sub-catchment scale: typhoid and its environmental determinants in Central Division, Fiji. EcoHealth 13:633-51. 
Johnston, F. H., Henderson, S. B., Chen, Y. et al. 2012. Estimated global mortality attributable to smoke from landscape fires. Environmental Health Perspectives 120:695-701.

Jones, K. E., Patel, N. G., Levy, M. A. et al. 2008. Global trends in emerging infectious diseases. Nature 451:990.

King, M. 1990. Health is a sustainable state. The Lancet 336:664-67.

Kmietowicz, Z. 2017. Red meat consumption is linked to higher risk of death from most major causes. BMJ 357:j2241.

Koplitz, S. N., Mickley, L. J., Marlier, M. E. et al. 2016. Public health impacts of the severe haze in Equatorial Asia in September-October 2015: Demonstration of a new framework for informing fire management strategies to reduce downwind smoke exposure. Environmental Research Letters 11:094023.

Kowarik, I. and Von Der Lippe, M. 2018. Plant population success across urban ecosystems: A framework to inform biodiversity conservation in cities. Journal of Applied Ecology 55:2354-61

Landrigan, P. J., Fuller, R., Acosta, N. J. R. et al. 2018. The Lancet Commission on Pollution and Health. The Lancet 391:462-512.

Langbein, J. 2017. Firewood, smoke and respiratory diseases in developing countries - the neglected role of outdoor cooking. PLoS ONE 12(6):e0178631.

Lappé, F., Clapp, J., Anderson, M. and Al, E. 2013. Framing Hunger: A Response to The State of Food Insecurity in the World 2012. Cambridge, MA: Small Planet Institute. Available at: www .iatp.org/documents/framing-hunger-a-response-to-the-state-of-food-insecurity-in-theworld-2012 (Accessed 4 January 2019).

Livesley, S., Mcpherson, E. and Calfapietra, C. 2016. The urban forest and ecosystem services: Impacts on urban water, heat, and pollution cycles at the tree, street, and city scale. Journal of Environmental Quality 45:119-24.

Lopez, P. 2008. The subversive links between HIV/AIDS and the forest sector. In Colfer, C. J. P. (ed.) Human health and forests: A global overview of issues, practice and policy. London: Earthscan, pp. 221-38.

Maller, C., Townsend, M., Pryor, A., Brown, P. and St Leger, L. 2006. Healthy nature healthy people: 'Contact with nature' as an upstream health promotion intervention for populations. Health Promotion International 21:45-54.

Manes, F., Marando, F., Capotorti, G. et al. 2016. Regulating ecosystem services of forests in ten Italian metropolitan cities: Air quality improvement by PM10 and $\mathrm{O}_{3}$ removal. Ecological indicators 67:425-40.

Masera, O. R., Bailis, R., Drigo, R., Ghilardi, A. and Ruiz-Mercado, I. 2015. Environmental burden of traditional bioenergy use. Annual Review of Environment and Resources 40:121-50.

McFarlane, R. A., Butler, C. D., Maynard, S., Cork, S. and Weinstein, P. 2018. Ecosystem-based translation of health research: Expanding frameworks for environmental health. Australian and New Zealand Journal of Public Health 42:437-40.

McFarlane, R. A., Sleigh, A. C. and Mc Michael, A. J. 2012. Synanthropy of wild mammals as a determinant of emerging infectious diseases in the Asian-Australasian region. EcoHealth 9:24-35. 
Meadows, D., Meadows, D., Randers., J. and Behrens III, W. 1972. The limits to growth. New York: Universe Books.

Miettinen, J., Hooijer, A., Vernimmen, R., Liew, S. C. and Page, S. E. 2017. From carbon sink to carbon source: Extensive peat oxidation in insular Southeast Asia since 1990. Environmental Research Letters 12(2):024014.

Millennium Ecosystem Assessment 2005. Ecosystems and human well-being: Biodiversity synthesis, Washington, DC: World Resources Institute.

Moyle, W., Jones, C., Dwan, T. and Petrovich, T. 2017. Effectiveness of a virtual reality forest on people with dementia: A mixed methods pilot study. The Gerontologist 58:478-87.

Oglethorpe, J., Honzak, C. and Margoluis, C. 2008. Healthy people, healthy ecosystems: A manual for integrating health and family planning into conservation projects. Washington DC: WWF.

Ohenjo, N. O., Willis, R., Jackson, D., Nettleton, C., Good, K. and Mugarura, B. 2006. Health of indigenous people in Africa. The Lancet 367:1937-46.

O'Sullivan, J. N. 2017. Synergy between population policy, climate adaptation and mitigation. In Hossain, M., Hales, R. and Sarker, T. (eds.) Pathways to a sustainable economy: Bridging the gap between Paris Climate Change Commitments and Net Zero Emission. Springer International Publishing, pp. 103-25

Page, S. E., Siegert, F., Rieley, J. O. et al. 2002. The amount of carbon released from peat and forest fires in Indonesia during 1997. Nature 420:61.

Population Institute 2015. Demographic vulnerability: Where population growth poses the greatest challenges. Available at: www.populationinstitute.org/resources/reports/dvi/ (Accessed 4 February 2019).

Potter, J. D. 2017. Red and processed meat, and human and planetary health. BMJ 357:j2190.

Prescott, S. L., Millstein, R. A., Katzman, M. A. and Logan, A. C. 2016. Biodiversity, the human microbiome and mental health: Moving toward a new clinical ecology for the 21st century? International Journal of Biodiversity 2016:1-18.

Pulliam, J. R. C., Epstein, J. H., Dushoff, J. et al. 2012. Agricultural intensification, priming for persistence and the emergence of Nipah virus: A lethal bat-borne zoonosis. Journal of the Royal Society Interface 9:89-101.

Real, R., Olivero, J., Fa, J. E. et al. 2017. The biogeographic basis of Ebola-virus disease outbreaks: A model for other zoonotic diseases? Bogor: CIFOR.

Reyes-García, V., Guèze, M., Luz, A. C. et al. 2013. Evidence of traditional knowledge loss among a contemporary indigenous society. Evolution and Human Behavior 34:249-57.

Riahi, K., van Vuuren, D. P. and Kriegler, E. 2017. The shared socioeconomic pathways and their energy, land use and greenhouse gas emissions implications: An overview. Global Environmental Change 42:153-168.

Rook, G. A. 2013. Regulation of the immune system by biodiversity from the natural environment: An ecosystem service essential to health. Proceedings of the National Academy of Sciences of the United States of America 110:18360-67. 
Searchinger, T., Hanson, C., Waite, R. et al. 2013. Achieving replacement level fertility. Working Paper, Installment 3 of Creating a sustainable food future. Washington, DC: World Resources Institute.

Seidl, R., Thom, D., Kautz, M. et al. 2017. Forest disturbances under climate change. Nature Climate Change 7:395.

Sforza, G. G. R. and Marinou, A. 2017. Hypersensitivity pneumonitis: A complex lung disease. Clinical and Molecular Allergy 15:6.

Sharp, P. M. and Hahn, B. H. 2011. Origins of HIV and the AIDS pandemic. Cold Spring Harbor Perspectives in Medicine 1(1):a006841.

Starbird, E., Norton, M. and Marcus, R. 2016. Investing in family planning: Key to achieving the Sustainable Development Goals. Global Health: Science and Practice 4:191-210.

Steffen, W., Richardson, K., Rockström, J. et al. 2015. Planetary boundaries: Guiding human development on a changing planet. Science 347:736-46.

Taylor, M. S., Wheeler, B. W., White, M. P., Economou, T. and Osborne, N. J. 2015. Research note: Urban street tree density and antidepressant prescription rates-a cross-sectional study in London, UK. Landscape and Urban Planning 136:174-79.

Tomita, A., Vandormael, A. M., Cuadros, D. et al. 2017. Green environment and incident depression in South Africa: A geospatial analysis and mental health implications in a resource-limited setting. The Lancet Planetary Health 1:e152-e162.

Tucker Lima, J. M., Vittor, A., Rifai, S. and Valle, D. 2017. Does deforestation promote or inhibit malaria transmission in the Amazon? A systematic literature review and critical appraisal of current evidence. Philosophical Transactions of the Royal Society B: Biological Sciences 372(1722):20160125.

Vasconcelos, P. F., Travassos Da Rosa, A., Rodrigues, S. G. et al. 2001. Inadequate management of natural ecosystem in the Brazilian Amazon region results in the emergence and reemergence of arboviruses. Cadernos de Saúde Pública 17:S155-S164.

Wallace, R. G., Gilbert, M., Wallace, R. et al. 2014. Did Ebola emerge in West Africa by a policydriven phase change in agroecology? Ebola's social context. Environment and Planning A 46:2533-42.

Webb, K., Jennings, J. and Minovi, D. 2018. A community-based approach integrating conservation, livelihoods, and health care in Indonesian Borneo. The Lancet Planetary Health 2:S26.

WHO 2015. Connecting global priorities: biodiversity and human health. World Health Organization and Secretariat of the Convention on Biological Diversity. Geneva: WHO. WHO 2018a. World Malaria Report 2018. Geneva: WHO.

WHO 2018b. Waterborne disease related to unsafe water and sanitation. Available at: www.who .int/sustainable-development/housing/health-risks/waterborne-disease/en/ (Accessed 5 December 2018).

WHO 2018c. Global Health Estimates: Disease burden by cause, age, sex, by country and by region, 2000-2016. Geneva, WHO. Available at: www.who.int/healthinfo/global_burden_disease/ estimates/en/index1.html (Accessed 5 January 2018). 
WHO 2019a. Global Health Observatory data (HIV/AIDs). Available at: www.who.int/gho/hiv/en/ (Accessed 4 January 2019).

WHO 2019b. WHO remains firmly committed to the principles set out in the preamble to the Constitution. Available at: www.who.int/about/who-we-are/constitution (Accessed 28 July 2019).

Willis, K. J. and Petrokofsky, G. 2017. The natural capital of city trees. Science 356:374-76.

Wilson Center 2013. Gorillas and Family Planning: At the Crossroads of Community Development and Conservation. Environmental Change and Security Program. Available at: www.wilsoncenter .org/event/gorillas-and-family-planning-the-crossroads-community-development-andconservation (Accessed 5 December 2018).

World Bank 2008. Forests sourcebook: Practical guidance for sustaining forests in development cooperation (English). Washington, DC: World Bank. Available at: http://documents .worldbank.org/curated/en/356731468155739082/Forests-sourcebook-practical-guidancefor-sustaining-forests-in-development-cooperation (Accessed 4 February 2019).

World Health Organisation 1986. Ottawa Charter for Health Promotion: First International Conference on Health Promotion Ottawa, 21 November 1986. Available at: www .healthpromotion.org.au/images/ottawa_charter_hp.pdf (Accessed 28 July 2019).

WWF 2018. Palm oil. Available at: www.worldwildlife.org/industries/palm-oil (Accessed 4 February 2019).

Wynes, S. and Nicholas, K. A. 2017. The climate mitigation gap: Education and government recommendations miss the most effective individual actions. Environmental Research Letters 12:074024.

Yang, J., Mcbride, J., Zhou, J. and Sun, Z. 2005. The urban forest in Beijing and its role in air pollution reduction. Urban Forestry \& Urban Greening 3:65-78. 